\title{
MENINKATKAN PROSES DAN HASIL BELAJAR IPA MELALUI MODEL PEMBELAJARAN KOOPERATIF TIPE STAD DI KELAS VIII SMPN 1 PUJUT
}

\author{
Lahim \\ Guru SMP Negeri 1 Pujut, lahim@gmail.com
}

\begin{tabular}{l} 
INFO ARTIKEL \\
Riwayat Artikel: \\
Diterima: 01-04-2018 \\
Disetujui: 30-04-2018 \\
\hline
\end{tabular}

Kata Kunci:

Pembelajaran

kooperatif, STAD,

proses belajar,

hasil belajar

\begin{abstract}
ABSTRAK
Abstrak: Dilaksanakan Penelitian Tindakan Kelas dalam tiga siklus dengan tujuan mendeskripsikan peningkatan hasil dan proses pembelajaran pada siswa kelas VIII SMPN 1 Pujut Tahun 2014/2015. Data yang dianalisis berupa data observasi aktivitas, quisioner, dan tes hasil belajar. Hasil aktivitas siswa kategori sangat aktif: 23,3 siklus I, 23,2 siklus II, dan 24,2 siklus III. Aktivitas guru kategori sangat aktif rata-rata 14 pada ketiga siklus. Ketuntasan klasikal aspek kognitif 74\% pada siklus I, $83 \%$ pada siklus 2, dan $91 \%$ pada siklus 3. Disimpulkan bahwa penerapan model pembelajaran kooperatif tipe STAD dapat meningkatkan proses dan hasil belajar belajar kelas VIII SMPN 1 Pujut tahun Pelajaran 2014/2015.
\end{abstract}

\begin{abstract}
Classroom Action Research was conducted in three cycles with the aim of describing the improvement of results and learning process in the students of grade VIII SMPN 1 Pujut Year 2014/2015. The data were analyzed in the form of activity observation data, quisioner, and test of learning result. The results of student activity categories are very active: 23.3 cycles I, 23.2 cycles II, and 24.2 cycles III. Activity teacher category is very active on average 14 on the third cycle. Classical completeness of cognitive aspect $74 \%$ in cycle I, $83 \%$ in cycle 2 , and $91 \%$ in cycle 3 . It is concluded that the application of STAD type cooperative learning model can improve the process and learning outcomes of class VIII SMPN 1 Pujut Lesson 2014/2015.
\end{abstract}

\section{A. LATAR BELAKANG}

Konteks KBK (Kurikulum Berbasis Kompetensi) Tahun 2004, pembelajaran diarahkan untuk mengembangkan kemampuan dalam mengetahui, memahami, melakukan sesuatu, hidup dalam kebersamaan, dan mengaktualisasikan diri. Dengan demikian kegiatan pembelajaran perlu:

1. Berpusat pada peserta didik (Student-Centered);

2. Mengembangkan kreativitas peserta didik;

3. Menciptakan kondisi menyenangkan dan menantang;

4. Bermuatan nilai, etika, estetika, logika, dan kinestetika; dan

5. Menyediakan pengalaman belajar yang beragam (Sanjaya, 2006: 102-103).

Selanjutnya dalam KBK, siswa dikatakan telah mencapai ketuntasan belajar apabila siswa telah mampu menguasai minimal $75 \%$ dari keseluruhan materi (khusus untuk pelajaran-pelajaran yang memiliki tingkat kesulitan lebih tinggi seperti MIPA) secara individual (Ghofur, 2004), serta apabila $\geq 85 \%$ dari seluruh siswa telah mencapai ketuntasan belajar sebesar 75 \% secara klasikal (Depdiknas, 2003).

Fakta yang kami temukan di lapangan, berdasarkan hasil observasi dan kajian selama pelaksanaan tugas pembelajaran di SMPN 1 Pujut bahwa tingkat ketuntasan belajar untuk mata pelajaran IPA(Fisika) pada kelas VIII belum optimal dengan
Kriteria Ketuntasan Minimal (KKM) yang ditentukan sekolah sebesar 70 (masih dibawah Standar Ketuntasan $75 \%$ secara individual). Gambaran situasi ini dapat dilihat pada tabel berikut :

TABEL 1

RATA-RATA PEROLEHAN NILAI SISWA

\begin{tabular}{|c|l|c|c|}
\hline No & Jenis Evaluasi & $\begin{array}{c}\text { Rata- } \\
\text { Rata } \\
\text { Nilai }\end{array}$ & $\begin{array}{c}\text { Persentase } \\
\text { Ketuntasan Secara } \\
\text { Klasikal }\end{array}$ \\
\hline 1 & $\begin{array}{l}\text { Ulangan harian } \\
1 \text { dan 2 }\end{array}$ & 65,6 & $71,8 \%$ \\
\hline 2 & $\begin{array}{l}\text { Ulangan Akhir } \\
\text { Semester 1 }\end{array}$ & 71,2 & $78,3 \%$ \\
\hline 3 & $\begin{array}{l}\text { Nilai Raport } \\
\text { smst 1 Siswa }\end{array}$ & 69,0 & $72,8 \%$ \\
\hline
\end{tabular}

Berdasarkan tabel di atas, dapatlah dikatakan bahwa ketuntasan belajar siswa kelas VIII SMP Negeri 1 Pujut pada pelajaran IPA ( Fisika) masih belum optimal. Hal ini disebabkan oleh adanya beberapa kemungkinan, antara lain:

1. Input siswa belum terseleksi secara tepat, karena semua calon peserta didik yang mendaftar di Sekolah ini harus diterima dengan usaha dan cara yang ditempuh masyarakat orang tua calon peserta didik tersebut. 
2. Motivasi belajar siswa tergolong masih rendah.

3. Kurangnya buku-buku pelajaran yang menunjang tercapainya ketuntasan belajar siswa.

4. Metode yang digunakan guru dalam pembelajaran masih dominan menggunakan metode pengajaran klasikal dan ceramah, tanpa banyak diselingi metode yang menantang siswa untuk berusaha.

Peristiwa utama yang kami hadapi di kelas ini ialah siswa kurang berpartisifasi, kurang terlibat, dan tidak punya inisiatif serta kontribusi baik secara intelektual maupun emosional, sehingga pengajaran cenderung bersifat kaku dan terpusat pada guru (TeacherCentered).

Seiring dengan adanya perubahan pardigma dalam dunia pendidikan yaitu dari pembelajaran yang berpusat pada guru (Teacher Centered) menjadi pembelajaran yang lebih berorientasi pada siswa (Student-Centered) sepertinya ini akan lebih efektif dalam hal mengoptimalkan proses pembelajaran dan meningkatkan hasil belajar siswa.

Beberapa hasil penelitian menunjukkan bahwa pembelajaran kooperatif (salah satu model pembelajaran yang bersifat Student-Centered) memiliki dampak positif terhadap siswa yang rendah hasil belajarnya. Dalam pembelajaran kooperatif siswa yang pandai membantu siswa yang memiliki kemampuan kurang (Daud, 2005: 204).

Menurut Slavin (1995: 5), dikenal beberapa tipe pembelajaran kooperatif di antaranya: Student TeamsAcheivement Division (STAD), Teams-GamesTournament (TGT), Jigsaw II, Cooperative Integrated Reading and Composition (CIRC), dan Team Accelered Instruction (TAI). Model pembelajaran kooperatif tipe STAD sangat cocok digunakan untuk mengajarkan tujuan pembelajaran yang dirumuskan dengan satu jawaban seperti yang terdapat dalam matematika dan IPA. Dengan demikian model tersebut juga cocok diterapkan dalam pembelajaran kimia (Nur, 1998) dalam Tanrere ( 2005: 268). Penelitian yang dilakukan oleh Jasri Jangi (2005) dan Tanrere (2005) juga menemukan bahwa model pembelajaran kooperatif tipe STAD dapat mengoptimalkan proses pembelajaran serta meningkatkan hasil belajar siswa pada mata pelajaran kimia.

Oleh sebab itulah, peneliti sangat tertarik untuk mencoba melakukan PTK penerapan model pembelajaran kooperatif tipe STAD di kelas VIII SMPN 1 Pujut tahun ajaran 2014/2015 . Dengan harapan model pembelajaran ini akan dapat mengoptimalkan proses pembelajaran serta meningkatkan hasil belajar siswa.

\section{B. METODE PENELITIAN}

\section{Jenis Penelitian}

Penelitian yang telah dilaksanakan adalah penelitian tindakan kelas (PTK), suatu penelitian yang bertujuan untuk meningkatkan atau memperbaiki praktik pembelajaran ke arah yang seharusnya dilakukan oleh guru dalam mengajar (Indrawati dan Maman, 2001: 12).

\section{Subyek Penelitian}

Subyek penelitian ini adalah siswa kelas VIII semester genap SMPN 1 Pujut Kabupaten Lombok Tengah tahun Pelajaran 2014/2015 yang berjumlah 46 orang, terdiri atas 12 orang siswa laki - laki dan 34 orang siswa perempuan .

\section{Variabel Penelitian}

Variabel Yang akan diselidiki dalam penelitian ini adalah:

a. Hasil belajar : peningkatan hasil belajar siswa setelah mengikuti pembelajaran dengan model pembelajaran kooperatif tipe STAD pada konsep kelarutan dan hasil kali kelarutan.

b. Proses belajar : aktivitas guru dan siswa dalam pembelajaran.

\section{Rancangan Penelitian}

Rancangan penelitian ini menggunakan rancangan penelitian tindakan kelas (PTK) yang terdiri dari 3 (tiga) siklus, dengan empat (4) tahapan yang saling terkait dan berkesinambungan: (1) perencanaan (planning), (2) pelaksanaan/tindakan (action), (3) pengamatan (observing), dan (4) refleksi (reflecting) (Suprayekti, 2003: 26). Secara lebih lengkap desain PTK ini digambarkan oleh Indrawati dan Maman (2001: 15). Tahapan-tahapan penelitian tindakan kelas ini diuraikan sebagai berikut:

\section{a. Siklus Pertama}

Pelaksanaan siklus pertama dengan Standar Kompetensi : 2.Menerapkan konsep dan prinsip mekanika klasik sistem kontinue dalam menyelesaikan masalah., dengan Kompetensi Dasar: 2.2. Memformulasikan hubungan antara konsep torsi, momentum sudut, dan moment inersia berdasarkan hukum 2 Newton serta penerapannya dalam masalah benda tegar, dengan 2 (dua) indikator yaitu :

a) Memformulasikan pengaruh torsi pada sebuah benda dalam kaitannya dengan gerak rotasi benda tersebut.

b) Mengungkap analogi hukum II Newton tentang gerak translasi dan gerak rotasi

Langlah-langkah kegiatan dilakukan sebagai berikut :

\section{Perencanaan}

Adapun kegiatan yang akan dilakukan dalam tahap perencanaan ini adalah penyusunan perangkat pembelajaran, antara lain:

a) Bahan ajar : berupa lembar diskusi siswa (LDS) berdasarkan Kurikulum Berbasis Kompetensi (KBK) dan silabus yang telah dikembangkan oleh guru. 
b) Rencana Pelaksanaan Pembelajaran (RPP) yang dikembangkan berdasarkan model kooperatif tipe STAD.

c) Tugas-tugas yang harus diselesaikan oleh kelompok dalam diskusi kelompok.

d) Quiz: instrumen untuk mengetahui peningkatan kualitas hasil belajar siswa.

e) Lembar observasi: untuk melihat bagaimana proses pembelajaran di kelas ketika diterapkan model pembelajaran kooperatif tipe STAD.

\section{Pelaksanaan}

Kegiatan yang akan dilakukan dalam tahapan ini adalah implementasi rencana tindakan yang telah dibuat pada tahap perencanan.

3. Observasi

Observasi dilakukan untuk mengetahui sejauh mana pelaksanaan tindakan sesuai dengan rencana yang telah disusun sebelumnya. Observasi dilakukan dengan:

a) Mengisi daftar cek observasi setiap kali pembelajaran dengan model kooperatif tipe STAD dilakukan.

b) Mencatat kejadian - kejadian penting di kelas saat pembelajaran berlangsung.

c) Melaksanakan tes/quiz pada akhir siklus.

\section{Analisis dan Refleksi}

Analisis dan refleksi dilakukan dengan langkah-langkah sebagai berikut:

a) Mendeskripsikan data-data yang terkumpul antara lain: data observasi, tanggapan siswa, dan hasil belajar pada akhir tindakan.

b) Mengolah dan menginterpretasikan data

c) Membuat refleksi terhadap data yang terkumpul dan membuat rencana tindakan selanjutnya.

\section{b. Siklus Kedua}

Pelaksanaan siklus kedua dengan Standar Kompetensi : 2.Menerapkan konsep dan prinsip mekanika klasik sistem kontinue dalam menyelesaikan masalah., dengan Kompetensi Dasar : 2.1. .Memformulasikan hubungan antara konsep torsi, momentum sudut, dan moment inersia berdasarkan hukum 2 Newton serta penerapannya dalam masalah benda tegar, dengan 2 (dua) indikator yaitu :

a) Menggunakan konsep momen inersia untuk berbagai bentuk benda tegar

b) Memformulasikan hukum kekekalan momentum

Pada siklus kedua ini dilakukan tahap-tahap seperti pada siklus pertama tetapi didahului dengan perencanaan ulang untuk memperbaiki kekurangan dan kelemahan pada pembelajaran siklus pertama.

\section{c. Siklus Ketiga}

Pelaksanaan siklus ketiga dengan Standar kompetensi: 2.Menerapkan konsep dan prinsip mekanika klasik sistem kontinue dalam menyelesaikan masalah., dengan Kompetensi Dasar : 2.1. Memformulasikan hubungan antara konsep torsi, momen tum sudut, dan moment inersia berdasarkan hukum 2 Newton serta penerapannya dalam masalah benda tegar, dengan 1 (satu) indikator yaitu : Menerapkan konsep titik berat benda dalam kehidupan seharihari

Pada siklus ketiga ini dilakukan tahaptahap seperti pada siklus pertama dan kedua tetapi didahului dengan perencanaan ulang untuk memperbaiki kekurangan dan kelemahan pada pembelajaran siklus pertama dan kedua.

\section{Instrumen Penelitian}

a. Lembar Observasi

Lembar observasi digunakan untuk memperoleh gambaran tentang proses pembelajaran menggunakan model kooperatif tipe STAD (Studen Team Achievement Devision) yang berkaitan dengan aktivitas guru dan aktivitas siswa selama proses pembelajaran.

b. Quisioner

Untuk mengetahui sikap dan tanggapan (afektif) siswa dalam mengikuti pembelajaran dengan model pembelajaran kooperatif tipe STAD siswa diberikan angket yang berisi 7 indikator sikap/tanggapan yang disusun dan dikembangkan sendiri oleh peneliti diakhir setiap pertemuan (lampiran 2).

c. Tes Hasil Belajar

1) Bentuk Instrumen

Instrumen untuk mengukur aspek kognitif siswa disusun oleh peneliti dalam bentuk soal uraian objektif yang terdiri dari 6 butir soal pada siklus 1, 6 butir soal pada siklus 2, dan 7 butir soal pada siklus 3 .

Untuk mengetahui keterampilan psikomotorik siswa pada konsep kelarutan dan hasil kali kelarutan. Tes diberikan dalam bentuk unjuk kerja yang dilakukan di akhir siklus 3 .

2) Verifikasi Tes Hasil Belajar Verifikasi tes hasil belajar dilakukan untuk mengetahui tingkat kesukaran soal, daya pembeda, dan reliabilitasnya. Tingkat kesukaran dihitung dengan rumus :

$$
T K=\frac{\text { Rata }- \text { rata }}{\text { Skor Maksimal }}
$$

Daya pembeda soal dihitung dengan rumus:

$$
D P=\frac{(\text { Rata }- \text { rata KA })-(\text { Rata }- \text { rata KB })}{\text { Skor Maksimal }}
$$


Reliabilitas soal dihitung dengan rumus: (Arikunto, 2005: 210)

$$
r_{11}=\left(\frac{n}{n-1}\right)\left(\frac{\sum \sigma_{i}^{2}}{\sigma_{\text {tot }}^{2}}\right)
$$

Hasil analisis masing-masing dapat dilihat pada tabel 3.1 berikut:

Rata-rata soal pada tiap siklus memiliki tingkat kesukaran dengan kategori mudah, namun tidak ada soal yang memiliki nilai tingkat kesukaran sama dengan 1 (satu). Demikian juga daya pembeda soal tiap siklus rata-rata kategori jelek, namun tidak ada satupun soal yang memiliki daya pembeda dengan nilai negatif. Sedangkan analisis reliabilitas soal menunjukkan bahwa soal yang digunakan pada setiap siklus sudah reliabel. Dengan demikian soal-soal tersebut dapat digunakan untuk mengukur hasil belajar aspek kognitif siswa.

\section{Teknik Pengumpulan Data}

Data yang dikumpulkan berupa data hasil observasi dan data hasil quiz/tes belajar siswa.

a. Data Observasi

Data observasi diperoleh dari pengamatan langsung, dilakukan dengan cara: (a) mengisi daftar cek observasi setiap kali pembelajaran dengan model kooperatif tipe STAD dilakukan, (b) mencatat kejadiankejadian penting di kelas saat pembelajaran berlangsung.

b. Quisioner

Data sikap (afektif) siswa diperolah dengan memberikan angket pada akhir setiap pembelajaran.

c. Data Tes Hasil Belajar

Data aspek kognitif siswa diperoleh dengan memberikan quiz di akhir setiap pembelajaran tiap siklus.

\section{Teknik Analisis Data}

Analisis ini digunakan untuk menginterpretasikan hasil observasi pembelajaran serta data quisioner/angket tanggapan/sikap (afektif) siswa. Data hasil observasi dianalisis dengan langkah-langkah sebagai berikut:

a. Menganalisis dan merangkum hasil observasi untuk setiap siklus dengan berdasarkan hasil cek lembar observasi.

b. Menganalisis dan merangkum hasil observasi tentang aktivitas/langkah-langkah guru dalam menerapkan pembelajaran menggunakan model pembelajaran kooperatif tipe STAD. Indikator aktivitas guru mencakup:

(1) keaktifan guru dalam membim bing siswa, (2) kemampuan guru dalam menciptakan suasana kelas yang kondusif, dan (3) guru memberikan materi pelajaran yang akan didiskusikan.

c. Menganalisis dan merangkum hasil observasi tentang aktivitas siswa dalam mengikuti pembelajaran dengan model kooperatif tipe STAD. Indikator aktivitas siswa mencakup: (1) antusias siswa dalam mengikuti KBM, (2) interaksi siswa dengan guru, (3) interaksi siswa dengan siswa, (4) kerjasama kelompok, (5) aktivitas siswa dalam diskusi kelompok, (6) aktivitas siswa dalam mengikuti pembelajaran, dan (7) partisipasi siswa dalam menyimpulkan hasil belajar.

Untuk mengetahui profil aktivitas siswa dan guru dalam pembelajaran dengan model kooperatif tipe STAD serta profil sikap/afektif siswa digunakan kategori dari Haris (2002: 1414) sebagai berikut:

$\mathrm{Mh}+1,5$ Sdh ke atas sangat aktif/sangat baik

$\mathrm{Mh}+0,5 \mathrm{Sdh} \mathrm{s} / \mathrm{d} \mathrm{Mh}+1,5 \mathrm{Sdh}=$ aktif/baik

$\mathrm{Mh}-0,5 \mathrm{Sdh} \mathrm{s} / \mathrm{d} \mathrm{Mh}+0,5 \mathrm{Sdh}=\quad$ cukup aktif/cukup baik

Mh $-1,5$ Sdh s/d Mh $-0,5$ Sdh = $\quad$ kurang aktif/kurang baik

Kurang dari Mh - 1,5 Sdh sangat kurang aktif/sangat kurang baik

Di mana: $\mathrm{Mh}=\frac{(X t h+X r h)}{2}$ dan $\mathrm{Sdh}=$ $\frac{(X t h-X r h)}{6}$

Keterangan:

$\mathrm{Mh} \quad=$ nilai rata-rata harapan

Sdh = standar deviasi harapan

Xth = nilai tertinggi harapan

$\mathrm{Xrh}=$ nilai terendah harapan

Analisis ini digunakan untuk menginterpretasikan data tes hasil belajar: Aspek Kognitif

Hasil tes kemampuan kognitif dihitung dengan langkah-langkah sebagai berikut:

1) Menghitung skor siswa perbutir soal dengan rumus: (Ghofur, 2004: 46).

SBS $=\frac{a}{b} \times c$

SBS = skor butir soal, $\mathrm{a}=$ skor mentah yang diperoleh siswa untuk butir soal, b $=$ skor total maksimum soal, dan $\mathrm{c}=$ bobot soal

2) Menghitung skor total siswa dengan rumus: (Ghofur, 2004: 46)

STP $=\Sigma$ SBS

STP $=$ skor total siswa 
3) Menentukan nilai perkembangan siswa dengan kriteria yang diajukan oleh Slavin (1995:80).

4) Menghitung rata-rata nilai perkembangan tiap kelompok

5) Menentukan tingkat penghargaan untuk masing-masing kelompok dengan kriteria yang diajukan oleh Slavin (1995: 80).

6) Menghitung rata-rata hasil belajar siswa dicari dengan rumus berikut:

$$
M=\frac{\sum X}{N}
$$

Keterangan:

$\mathrm{M}=$ Mean (rata-rata); $\sum X=$ Jumlah nilai yang diperoleh seluruh siswa; $\mathrm{N}=$ Jumlah siswa

7) Menghitung ketuntasan belajar siswa secara klasikal dengan rumus:

$$
K B=\frac{X}{N} \times 100 \%
$$

Keterangan:

$\mathrm{KB}=$ Ketuntasan belajar secara

klasikal

$\mathrm{X}=$ Banyaknya siswa yang memperoleh nilai $\geq 70 \quad$ (KKM yang ditentukan sekolah untuk Kompetansi Dasar : 2.1.Memformulasikan hubungan antara konsep torsi, momentum sudut, dan moment inersia berdasarkan hukum 2 Newton serta penerapannya dalam masalah benda tegar.

$\mathrm{N}=$ Banyaknya siswa

\section{Indikator Kerja}

Yang menjadi indikator keberhasilan penelitian tindakan kelas ini adalah pencapaian ketuntasan belajar siswa dengan ketentuan sebagai berikut:

1. Tercapainya kriteria ketuntasan minimal (KKM) yang ditentukan sekolah yaitu sebesar 70

2. Apabila $85 \%$ siswa atau lebih di kelas tuntas belajar atau memperoleh nilai $\geq 70$

3. Apabila Proses Pembelajaran Sudah Berada Dalam Kategori Aktif

\section{HASIL DAN PEMBAHASAN}

\section{Data Observasi Aktivitas Siswa}

Data hasil observasi aktivitas siswa dalam mengikuti proses belajar mengajar dengan metode STAD ini diukur atau diperoleh dengan menggunakan pedoman observasi yang disusun sendiri oleh peneliti. Indikator untuk mengukur aktivitas belajar siswa ini terdiri dari
7 (tujuh) poin yaitu: (1) antusias siswa dalam mengikuti kegiatan belajar mengajar, (2) interaksi siswa dengan guru, (3) interaksi siswa dengan siswa, (4) kerjasama dalam kelompok, (5) aktivitas siswa dalam diskusi kelompok, (6) aktivitas siswa dalam belajar mengajar, dan (7) partisipasi siswa dalam menyimpulkan hasil belajar, yang masing-masing poin dijabarkan lebih lanjut oleh peneliti. Skor maksimal dapat diperoleh siswa sebesar 35 dan skor minimal sebesar 7 dengan ketentuan tingkat pencapaian sebagai

berikut: sangat aktif ( $23-28)$; aktif $(18-22)$; cukup aktif (12 - 17); kurang aktif $(7-11)$ dan sangat kurang aktif (1 - 7). Dalam mengumpulkan data ini, peneliti dibantu oleh observer yang bertugas melihat secara umum/menyeluruh aktivitas siswa dalam mengikuti kegiatan pembelajaran dengan model pembelajaran kooperatif tipe STAD menggunakan lembar pedoman observasi yang telah tersedia.

Dengan menggunakan pedoman di atas diperolah profil aktivitas siswa dalam mengikuti kegiatan pembelajaran dengan model pembelajaran kooperatif tipe STAD pada 3 (tiga) siklus sebagai berikut:

TABEL 2

PROFIL AKTIVITAS SISWA DALAM

\begin{tabular}{|c|c|c|c|c|}
\hline \multirow[b]{2}{*}{ No } & \multirow{2}{*}{$\begin{array}{c}\text { Aspek Yang } \\
\text { diamati }\end{array}$} & \multicolumn{3}{|c|}{ Skor Rata -rata tiap siklus } \\
\hline & & $\begin{array}{c}\text { siklus } \\
1\end{array}$ & $\begin{array}{l}\text { siklus } \\
2\end{array}$ & $\begin{array}{c}\text { siklus } \\
3\end{array}$ \\
\hline 1 & $\begin{array}{l}\text { Saya sangat } \\
\text { antusias dalam } \\
\text { mengikuti KBM }\end{array}$ & 3,5 & 3,6 & 3,6 \\
\hline 2 & $\begin{array}{l}\text { Pembelajaran ini } \\
\text { memberikan } \\
\text { banyak } \\
\text { kesempata ber } \\
\text { interaksi siswa } \\
\text { dengan guru }\end{array}$ & 3,3 & 3,3 & 3,5 \\
\hline 3 & $\begin{array}{l}\text { Pembelajaran ini } \\
\text { juga banyak } \\
\text { memberikan } \\
\text { kesempatan } \\
\text { berinteraksi } \\
\text { antara siswa } \\
\text { dengan siswa } \\
\text { lainnya. }\end{array}$ & 3,5 & 3,4 & 3,5 \\
\hline 4 & $\begin{array}{l}\text { Pembelajaran ini } \\
\text { mengutamakan } \\
\text { kerjasama dalam } \\
\text { kelompok yang } \\
\text { sangat } \\
\text { maksimal. }\end{array}$ & 3,3 & 3,4 & 3,5 \\
\hline 5 & $\begin{array}{l}\text { Aktivitas siswa } \\
\text { dalam diskusi } \\
\text { kelompok dapat } \\
\text { menggairahkan } \\
\text { semangat belajar } \\
\text { saya }\end{array}$ & 3,4 & 3,2 & 3,4 \\
\hline 6 & $\begin{array}{l}\text { Aktivitas siswa } \\
\text { dalam KBM }\end{array}$ & 3,0 & 3,0 & 3,3 \\
\hline
\end{tabular}

MENGIKUTI PEMBELAJARAN 


\begin{tabular}{|c|l|c|c|c|} 
& $\begin{array}{l}\text { sangat besar } \\
\text { sehingga tidak } \\
\text { membosankan }\end{array}$ & & & \\
\hline 7 & $\begin{array}{l}\text { Partisipasi siswa } \\
\text { dalam } \\
\text { menyimpulkan } \\
\text { hasil belajar } \\
\text { sangat besar. }\end{array}$ & 3,3 & 3,3 & 3,4 \\
\hline & Jumlah & 23,3 & 23,2 & 24,2 \\
\hline Klasifikasi & $\begin{array}{c}\text { Sangat } \\
\text { aktif }\end{array}$ & $\begin{array}{c}\text { Sangat } \\
\text { aktif }\end{array}$ & $\begin{array}{c}\text { Sangat } \\
\text { aktif }\end{array}$ \\
\hline
\end{tabular}

Berdasarkan data hasil observasi di atas terlihat jelas bahwa model pembelajaran kooperatif tipe STAD memiliki dampak positif terhadap aktivitas belajar siswa. Siswa menjadi menjadi lebih aktif dan partisipatif dalam melakukan kegiatan belajar.

1) Data Observasi Aktivitas Guru

Data hasil observasi aktivitas guru dalam proses belajar mengajar dengan metode STAD ini diukur atau diperoleh dengan menggunakan pedoman observasi yang disusun sendiri oleh peneliti. Indikator untuk mengukur aktivitas guru ini terdiri dari 3 (tiga) poin yaitu: (1) aktif dalam membimbing siswa, (2) mampu menciptakan suasana yang kondusif, (3) memberikan materi yang akan didiskusikan, dimana masing-masing poin dijabarkan lebih lanjut oleh peneliti. Skor maksimal dapat diperoleh siswa sebesar 15 dan skor minimal sebesar 3 dengan ketentuan tingkat pencapaian sebagai berikut: sangat aktif (12 - 15); aktif (10 11); cukup aktif (8 - 9); kurang aktif (6 - 7) dan sangat kurang aktif (3 - 5). Dalam mengumpulkan data ini, peneliti dibantu oleh observer yang bertugas melihat secara umum/menyeluruh aktivitas guru dalam melaksanakan kegiatan pembelajaran dengan model pembelajaran kooperatif tipe STAD menggunakan lembar pedoman observasi yang telah tersedia.

Dengan menggunakan pedoman di atas diperolah profil aktivitas guru dalam melaksanakan kegiatan pembelajaran dengan model pembelajaran kooperatif tipe STAD pada 3 (tiga) siklus sebagai berikut:

TABEL 3

PROFIL AKTIVITAS GURU DALAM

MELAKSANAKAN PEMBELAJARAN

\begin{tabular}{|c|l|c|c|c|}
\hline \multirow{2}{*}{ No. } & \multirow{2}{*}{ Kriteria } & \multicolumn{3}{|c|}{ Perolehan Rata-Rata } \\
\cline { 3 - 5 } & $\begin{array}{c}\text { Siklus } \\
\text { S }\end{array}$ & $\begin{array}{c}\text { Siklus } \\
\text { 2 }\end{array}$ & $\begin{array}{c}\text { Siklus } \\
\mathbf{3}\end{array}$ \\
\hline 1. & $\begin{array}{l}\text { Aktif dalam } \\
\text { membimbing } \\
\text { siswa }\end{array}$ & 4 & 5 & 5 \\
\hline 2. & $\begin{array}{l}\text { Mampu } \\
\text { menciptakan }\end{array}$ & 5 & 5 & 5 \\
\hline
\end{tabular}

\begin{tabular}{|c|c|c|c|c|}
\hline & $\begin{array}{l}\text { suasana yang } \\
\text { kondusif }\end{array}$ & & & \\
\hline 3. & $\begin{array}{l}\text { Memberikan } \\
\text { materi yang } \\
\text { akan } \\
\text { didiskusikan }\end{array}$ & 4 & 4 & 5 \\
\hline & Total Skor & 13 & 14 & 15 \\
\hline & Klasifikasi & $\begin{array}{l}\text { Sangat } \\
\text { Aktif }\end{array}$ & $\begin{array}{l}\text { Sangat } \\
\text { Aktif }\end{array}$ & $\begin{array}{c}\text { Sangat } \\
\text { Aktif }\end{array}$ \\
\hline
\end{tabular}

Berdasarkan data hasil observasi aktivitas guru dalam melaksanakan kegiatan pembelajaran dengan model pembelajaran kooperatif tipe STAD terlihat bahwa guru sangat aktif dalam hal membimbing siswa, menciptakan suasana belajar yang kondusif dalam kelas, dan dalam memberikan materi yang akan didiskusikan oleh siswa.

\section{Data Hasil Belajar Siswa}

Data hasil belajar aspek kognitif dalam penelitian ini diperoleh secara langsung dan seketika sehingga menggambarkan tingkat penguasaan siswa terhadap materi yang baru saja mereka selesai diskusikan. Tes untuk mengukur aspek kognitif siswa pada siklus pertama, kedua, dan ketiga disusun dalam bentuk tes uraian objektif. Hal ini karena soal uraian objektif paling bermanfaat untuk menguji jenjang berpikir kognitif yang tinggi. Khususnya, sasaran pengajaran pada jenjang analisis, sintesis, dan evaluasi, dapat diukur apabila siswa diminta menyusun dan mengungkapkan pikiran mereka dalam suatu kerangka terstruktur, menguraikan hubungan, dan mempertahankan pendapat secara tertulis (Jerrold, 1994: 230).

Tes uraian objektif pada siklus pertama terdiri dari 6 butir soal, pada siklus kedua terdiri dari 6 butir soal, dan pada siklus ketiga terdiri dari 7 butir soal sehingga total butir soal yang digunakan untuk mengukur hasil belajar siswa pada penelitian ini adalah 19 butir soal. Dari tabel hasil belajar di atas kita lihat bahwa skor maksimal yang dapat diperoleh siswa pada siklus pertama sebesar 100 (seratus) dan skor minimalnya 33,o.dengan tingkat ketuntasan $74 \%$. Berati harus dilanjutkan ke siklus berikutnya karena belum mencapai ketuntasan belajar $85 \%$. Sehingga diadakanlah penelitian selanjutnya dengan siklus kedua, setelah terlebih dahulu mengadakan revisi dan repleksi terhadap kegiatan pada siklus 1 sehingga dapat meminimalkan kekurangan yang terjadi pada siklus pertama. Setelah melakukan pembelajaran dan tes pada siklus kedua diperoleh skor tertinggi 100 dan nilai terendah 44 serta nilai rata - rata 75 sudah ada peningkatan jika dibandingkan dengan hasil yang di peroleh pada siklus pertama dengan ketuntasan belajar secara klasikal 83\%. Meskipun peningkatan hasil belajar pada pembelajaran siklus kedua ini namun kita masih belum mencapai indikator kerja dengan 
ketuntasan $85 \%$ sehingga harus dilanjutkan dengan penelitian tindakan kelas siklus ke tiga.

Setelah dilakukan revisi perangkat pembelajaran dan tidakan yang masih belum efektif pada siklus 1 dan 2 diadakan lagi pengambilan data pada siklus ketiga yang hasil belajarnya sudah ada pada tabel 4.3 di atas. Dari tabel hasil belajar siklus ke tiga di atas terlihat bahwa perolehan skor tertinggi 100, skor terendah 50 rata - rata kelas 82 dengan ketuntasan belajar klasikal adalah $91 \%$ dengan demikian target ketuntasan klasikal 85\% telah terlampaui dengan demikian pembelajaran dengan model kooperatif tipe STAD dapat menjadi model pembelajaran baik dalam meningkatkan hasil belajar siswa.

1) Data Hasil Belajar Aspek Afektif

Data aspek afektif siswa diperoleh dengan memberikan angket berisi tanggapan (sikap) siswa terhadap proses pembelajaran kooperatif tipe STAD. Angket tersebut disusun dan dikembangkan sendiri oleh peneliti dan berisi 7 butir indikator sikap siswa dengan 4 kategori, yaitu: sangat setuju, setuju, kurang setuju, dan tidak setuju (lampiran ). Skor maksimal diperoleh siswa sebesar 28 dan skor minimalnya 1 dengan ketentuan tingkat ketercapaian sebagai berikut: sangat kurang aktif $(1-6)$; kurang aktif $(7-12)$; cukup aktif $(13-17)$; aktif (18 - 22); dan sangat aktif (28 23). Dengan menggunakan kriteria di atas diperoleh data aspek afektif siswa pada 3 siklus tersebut pada tabel berikut:

TABEL 4

HASIL BELAJAR ASPEK AFEKTIF

\begin{tabular}{|c|l|c|c|c|}
\hline \multirow{2}{*}{$\begin{array}{l}\text { N } \\
\text { o. }\end{array}$} & \multicolumn{1}{|c|}{ Aspek yang diamati } & \multicolumn{3}{|c|}{$\begin{array}{c}\text { Perolehan Rata- } \\
\text { Rata Skor }\end{array}$} \\
\cline { 2 - 5 } 1. & $\begin{array}{l}\text { Siklu } \\
\text { S 1 }\end{array}$ & $\begin{array}{c}\text { Siklu } \\
\text { S 2 }\end{array}$ & $\begin{array}{c}\text { Siklu } \\
\text { S 3 }\end{array}$ \\
\hline 2alam mengikuti KBM & 3,5 & 3,6 & 3,6 \\
\hline $\begin{array}{l}\text { Pembelajaran ini } \\
\text { memberikan banyak } \\
\text { kesempata ber interaksi } \\
\text { siswa dengan guru }\end{array}$ & 3,3 & 3,3 & 3,5 \\
\hline 3. & $\begin{array}{l}\text { Pembelajaran ini juga } \\
\text { banyak memberikan } \\
\text { kesempatan berinteraksi } \\
\text { antara siswa dengan siswa } \\
\text { lainnya. }\end{array}$ & 3,5 & 3,4 & 3,5 \\
\hline 4. & $\begin{array}{l}\text { Pembelajaran ini } \\
\text { mengutamakan kerjasama } \\
\text { dalam kelompok yang } \\
\text { sangat maksimal. }\end{array}$ & 3,3 & 3,4 & 3,5 \\
\hline 5. & $\begin{array}{l}\text { Aktivitas siswa dalam } \\
\text { diskusi kelompok dapat } \\
\text { menggairahkan semangat } \\
\text { belajar saya }\end{array}$ & 3,4 & 3,2 & 3,4 \\
\hline 6. & $\begin{array}{l}\text { Aktivitas siswa dalam } \\
\text { KBM sangat besar } \\
\text { sehingga tidak } \\
\text { membosankan }\end{array}$ & 3,0 & 3,0 & 3,3 \\
\hline 7. & $\begin{array}{l}\text { Partisipasi siswa dalam } \\
\text { menyimpulkan hasil }\end{array}$ & 3,3 & 3,3 & 3,4 \\
\hline
\end{tabular}

\begin{tabular}{|l|c|l|l|}
\hline belajar sangat besar. & & & \\
\hline Total Skor & $\begin{array}{c}23, \\
3\end{array}$ & 23,2 & 24,2 \\
\hline Klasifikasi & SA & SA & SA \\
\hline
\end{tabular}

Data di atas menunjukkan bahwa tanggapan dan sikap siswa dalam mengikuti proses pembelajaran menggunakan model pembelajaran kooperatif tipe STAD pada konsep kelarutan dan hasil kali kelarutan pada ketiga siklus sangat baik. Beberapa siswa menyatakan secara langsung kepada peneliti baik secara lisan maupun berupa catatan kecil yang ditemukan peneliti di bagian belakang angket yang diisi siswa yang menyatakan bahwa mereka sangat senang belajar dengan metode STAD ini dibandingkan dengan metode lainnya. Karena dalam metode STAD siswa merasa lebih luwes berinteraksi langsung baik dengan guru maupun teman sejawatnya.

\section{SIMPULAN DAN SARAN}

\section{Simpulan}

Penerapan model pembelajaran kooperatif tipe STAD dapat meningkatkan proses pembelajaran di kelas VIII SMPN 1 Pujut tahun pelajaran 2014/2015, hal ini dapat dilihat dari aktivatas belajar siswa dan guru pada ketiga siklus berada pada kategori sanagat aktif dan telah melampaui indikator kerja pada target kriteria aktif.

a. Penerapan model pembelajaran kooperatif tipe STAD dapat meningkatkan hasil belajar siswa kelas VIII SMPN 1 Pujut tahun pelajaran 2014 / 2015, yang mencakup :

b. Aspek Kognitif dengan tingkat pencapaian sudah berada di atas KKM sekolah (sebesar 70) serta persentase ketuntasan belajar secara klasikal sudah berada di atas $85 \%$ pada siklus ke tiga..

c. Aspek afektif dengan tingkat pencapaian ratarata sudah berada dalam kategori sangat baik pada ketiga siklus.

\section{Saran-saran}

Berdasarkan proses dan hasil yang diperoleh peneliti dalam penelitian ini ada beberapa saran bagi pembaca sebagai berikut:

a. Penerapan model pembelajaran kooperatif tipe STAD sangat cocok pada konsep kelarutan dan hasil kali kelarutan namun hendaknya lebih cermat dalam menentukan alokasi waktu dan kompleksitas materi yang akan disampaikan.

b. Model pembelajaran kooperatif tipe STAD sangat cocok untuk meteri kimia yang menuntut penerapan rumus, sehingga diperlukan penelitian lanjutan untuk menguji keunggulan metode STAD pada konsep kimia lainnya.

c. Penggunaan variasi metode pembelajaran di kelas sangat dituntut dalam upaya peningkatan kualitas pembelajaran di kelas, model pembelajaran kooperatif tipe STAD merupakan salah satu alternatif model pembelajaran yang cukup tepat dalam menciptakan suasana kelas yang bersifat Student Centered. 


\section{UCAPAN TERIMA KASIH}

Dengan penuh rasa hormat, saya ucapkan teimakasih kepada: Kepala Dinas Pendidikan yang telah memfasilitasi, mengizinkan penulis untk mengadakan penelitian hingga dapat terlaksana dengan baik. Pengurus PGRI Kabupaten Lombok Tengah, dan Guruguru SMPN 1 Pujut yang telah memberi dukungan baik secara moral maupun tindakan langsung dalam pelaksanaan penelitian ini.

\section{DAFTAR RUJUKAN}

[1]. Daud, Amin, dkk.. 2005. Meningkatkan Aktivitas dan Prestasi Belajar Siswa Dalam Belajar Matematika Melalui Model Pembelajaran Kooperatif Tipe STAD (Student Teams Acheivement Division). Jurnal Ilmu Kependidikan Volume 2 Nomor 3. Makassar: LPMP Sulsel.

[2]. Departemen Pendidikan Nasional. 2003. Kurikulum 2004 SMA Pedoman Khusus Pengembangan Silabus Dan Penilaian Mata Pelajaran Kimia. Jakarta: Depdiknas.

[3]. Ghofur, Abdul. 2004. Pedoman Umum Pengembangan Penilaian Kurikulum Berbasis Kompetensi Sekolah Menengah Atas (SMA). Jakarta: Depdiknas.

[4]. Hamalik, Oemar. 1994. Pendekatan Baru Strategi Belajar Mengajar Berdasarkan CBSA. Bandung: Sinar Baru Algensindo.

[5]. Hamalik, Oemar. 1982. Media Pendidikan. Bandung : Alumni.

[6]. Indrawati dan Wijaya, Maman. 2001. Penelitian Tindakan Kelas (Classroom Action Research). Bandung: Pusat Penataran Guru IPA.

[7]. Ibrahim, M. (2002). Pengembangan Perangkat Pembelajaran. Modul : Bio-C-06 Direktorat Sekolah Lanjutan Tingkat Pertama Direktorat Jendral Pendidikan Dasar dan Menengah Depertemen Pendidikan Nasional.

[8]. Ismail. 2003. Model-Model Pembelajaran. Jakarta: Dit. Pendidikan Lanjutan Pertama.

[9]. Jasri Jangi, Muhammad, dkk. 2005. Peningkatan Partisipasi Siswa Dalam Mengikuti Mata Pelajaran Kimia melalui Model Pembelajaran Kooperatif Tipe STAD. Jurnal Ilmu Kependidikan Vol. 2 No.3. Makassar: LPMP Makassar.

[10]. Kemp, Jerrold E. (1994). Designing effective instruction. New York: MacMillan Publisher

[11]. Latuheru,J.D.1993,Media Pembelajaran dalam Proses Belajar-Mengajar Kini .Ujung Pandang : Penerbit IKIP Ujung Pandang.

[12]. Muntari. 2006. Produksi Video pembelajaran "Pembelajaran Kooperatif Tipe STAD" (Student team Achievement Devision). Malang: UNM.

[13]. Sanjaya, Wina. 2006. Pembelajaran Dalam Implementasi Kurikulum Berbasis Kompetensi. Jakarta: Kencana Prenada Media Group.

[14]. Slavin, R. E. 1995. Cooperative Learning Theory, Research, and Practice Second. Edition. Center For Research On Effective Schooling For Disadventaged Student The John Hopkins University. Allyn and Bacon.

[15].Suprayekti. 2003. Intereaksi Balajar Mengajar. Jakarta: Depdiknas.

[16]. Tanrere, Munir, dkk. 2005. Implementasi Model Pembelajaran Kooperatif Tipe Student Team Achievement Devision Untuk Meningkatkan Kualitas Proses dan Hasil Belajar Siswa SMA dalam Mata Pelajaran Kimia. Jurnal Ilmu Kependidikan Vol. 2 No. 3. Makassar: LPMP Sulsel. 